\title{
Agronomic Performance and Economics of Yield Loss Associated With Angular Leaf Spot Disease of Common Bean in the Southern Highlands of Tanzania
}

Rose Mongi, ${ }^{\dagger}$ University of KwaZulu-Natal, College of Agriculture, Engineering and Science, School of Agricultural, Earth and Environmental Sciences, Scottsville 3209, Pietermaritzburg, South Africa, and The Uyole Agricultural Research Institute, Mbeya, Tanzania; and Pangirayi Tongoona, Hussein Shimelis, and Julia Sibiya, University of KwaZulu-Natal, College of Agriculture, Engineering and Science. School of Agricultural, Earth and Environmental Sciences, Scottsville 3209, Pietermaritzburg, South Africa

\begin{abstract}
Angular leaf spot (ALS) caused by Pseudocercospora griseola is among the devastating diseases of common bean (Phaseolus vulgaris L.) in the Southern Highlands of Tanzania (SHT). This study was conducted to assess the agronomic performance and economics of yield loss associated with the disease on five bean cultivars that are widely grown by farmers. The cultivars were evaluated in a split plot design with a randomized complete block arrangement during 2012/2013 and 2013/2014. The main plots were two rates of fungicide and a control whereas the subplots consisted of cultivars. Data were collected on disease severity, yield, and yield components. Analysis of variance was

done and marginal rate of returns determined using partial budget. Results indicated significant decrease in yields, number of pods, seeds, and seed weight at $P<0.05$ for untreated plots. Decreases in yield were associated with ALS disease severity that in turn was influenced by cultivar and rate of fungicide used. Higher grain yield losses of as much as $61 \%$ and the lowest marginal rate of returns were recorded for unsprayed plots during heavy rains. Fungicide usage at the recommended rates should be considered during heavy rains and breeding for resistance should be taken as an economical and sustainable strategy for managing the disease.
\end{abstract}

Angular leaf spot (ALS) caused by Pseudocercospora griseola is one of the major diseases of common bean (Phaseolus vulgaris L.) in the Southern Highlands of Tanzania (SHT). Pseudocercospora griseola is a seed-borne pathogen that infects bean seedlings early in the season, and secondary infections occur rapidly under favorable conditions. The pathogen survives on infected seed, off-season bean plants, and saprophytically as mycelium and conidia in association with host residues on or near the soil surface (Waggoner and Berger 1987). Following infection, $P$. griseola produces a toxin which damages chloroplasts, resulting in red tissues contrasting with the normal green color (Cardona Alvarez and Walker 1956). Additionally, the pathogen has the ability to colonize intercellular spaces of the palisade cells of the leaf and other aerial parts resulting in angular lesions (Monda et al. 2001; Waggoner and Berger 1987). It has been reported that maximum disease development by $P$. griseola occurs between flowering and pod setting, a period characterized by an increase in the photosynthetic rate in common bean (Patterson et al. 1978). The occurrence of ALS at these stages of plant development reduces the net assimilation rate through a sink effect in which the causal pathogen diverts carbon fluxes from the growing seed for its own growth (Farrar 1992). As a result, seeds borne by infected plants are few, shriveled, and often discolored. Since seed yield of common bean is influenced by the number of pods per plant, number of seeds per pod, and average seed weight (Sinha 1977), reducing any of these yield components will lead to lower yields with an additional negative effect on seed quality (Stenglein et al. 2003). Yield reductions due to plant disease have also been documented on barley infected with Rhychosporium secalis and in peanuts infected with Cercosporium personatum (Bourgeois et al. 1991; Walters et al. 2014).

There are several methods that have been proposed to study the relationship between yield loss and disease severity. However, the most common is area under the disease progress curve (AUDPC),

\section{${ }^{\dagger}$ Corresponding author: R. Mongi; E-mail: rhmongi@yahoo.com}

This research was financially supported by the Ministry of Agriculture of Tanzania under Agriculture Sector Development Program.

Accepted for publication 27 July 2017.

C) 2018 The American Phytopathological Society a quantitative summary of disease intensity over time that directly links yield losses with diseases, and it has been used in potatoes, maize, rice, beans, and pea (Filho et al. 1997; Godoy et al. 2003; Simko and Piepho 2011; Su et al. 2001). This model considers the number of times disease severity is evaluated and the duration of the epidemic (Su et al. 2001). The AUDPC is useful especially for evaluating facultative (hemibiotrophic and nectrophic) pathogens like $P$. griseola that cause varying degrees of damage to plants throughout the growing period of the crop (Correa et al. 1989).

The economics of yield losses or gains on various crops can be determined from yield levels that provide the highest or lowest financial returns to investments in producing or protecting the crop against diseases (Egbe and Idoko 2010).Yield losses are expressed as the difference in yield between diseased and disease-free crops and can be determined in experimental plots using fungicide management (Lemessa et al. 2011; Madden and Nutter 1995; Sileshi et al. 2014).

This study was conducted to assess the agronomic performance and economics of yield loss associated with ALS on five widely grown bean cultivars as an effort toward developing sustainable control measures against $P$. griseola.

\section{Materials and Methods}

Description of the study area. This study was conducted at the Uyole Agricultural Research Institute (ARI-Uyole) located in the SHT. The Institute is situated at $8^{\circ} 53^{\prime} \mathrm{S}$ and $33^{\circ} 39^{\prime} \mathrm{E}$ at altitude of 1798 meters above sea level. The soils are loam and well drained, and the air temperature ranges from 18.0 to $23.7^{\circ} \mathrm{C}$ with a peak relative humidity of $95 \%$ during the rainy season. The location is characterized by unimodal rainfall that occurs between December and May, allowing for two plantings of common bean. This type of weather favors ALS disease development, and ARI-Uyole is one of the hot spots for ALS in the region. Additionally, the trial site had been planted with common bean in the previous years, ensuring abundant natural inocula from infested plant debris.

Experimental material and cultural procedures. Five cultivars of common bean widely grown and highly preferred by the farmers in the SHT, but ALS susceptible-Kablanketi, Maini, Kigoma, DRK (Uyole 96), and Kasukanywele (Uyole 94) — were used in the experiments. The seed was obtained from the local market where they are sold as farm-saved and untreated with fungicide. Kablanketi, Maini, and Kigoma are landraces, whereas DRK and Kasukanywele were 
released as improved cultivars more than twenty years ago. About one kilogram of seed was purchased for each variety. Four trials were conducted in 2012/2013 and 2013/2014: two at the beginning of the rainfall during heavy rains (December to March, with average rainfall of $668.9 \mathrm{~mm}$ ) and two toward the end of the rainy season (March to July, average rainfall $255.6 \mathrm{~mm}$ ) also known as the light rain season. Common beans are mainly planted twice in a year.

The trials were laid out in a split-plot arrangement of a randomized complete block design with three replications. The main plots were assigned to fungicide sprays while the subplots contained the five cultivars. Each subplot measured $2 \mathrm{~m} \times 3 \mathrm{~m}$ and consisted of five rows, each hand seeded with 32 seeds at $10-\mathrm{cm}$ intrarow and $50-\mathrm{cm}$ interrow spacing. Border rows of 'Dorea', highly susceptible to $P$. griseola, were planted in all of the four sides surrounding the trial to increase inoculum pressure. Agronomic practices including fertilizer applications ( $\mathrm{N}$ at $30 \mathrm{~kg} / \mathrm{ha}$ and $\mathrm{P}_{2} \mathrm{O}_{5}$ at $60 \mathrm{~kg} / \mathrm{ha}$ ) and weed management were as per recommendations for common bean production in the SHT. Plants were sprayed with insecticide (Actellic $50 \mathrm{EC})$ containing $500 \mathrm{ai} \mathrm{g} / \mathrm{ha}(49.02 \% \mathrm{w} / \mathrm{w})$ pirimiphos-methyl using a backpack sprayer 10 days after planting and at pod setting to protect the plants against the bean fly and bean pod borers.

Fungicide application. In all the four trials, the main plots consisted of three treatments: (i) "no fungicide treatment," where no fungicide was applied, a common practice with most of bean farmers; (ii) "farmers' practice" in which the fungicide is applied once at a rate of $50 \mathrm{ml} / \mathrm{ha}$ at late pod filling stage; and (iii) fungicide at the recommended rate of $400 \mathrm{ml} / \mathrm{ha}$ applied four times at vegetative stage, flower initiation, late flowering, and pod filling. A preventive foliar fungicide (Othello TOP; Sineria, Maastricht, The Netherlands) containing azoxystrobin $200 \mathrm{~g} /$ liter difenoconazole $125 \mathrm{~g} /$ liter SC commonly available in the SHT was used. The fungicide was applied using a backpack sprayer (SOLO) with an average flow rate of 400 liters/ha and a nozzle discharge of $500 \mathrm{ml} / \mathrm{min}$.

ALS disease evaluations. The trials were exposed to natural ALS inoculum. Disease severity was scored at 10-day intervals starting from the first appearance of the trifoliate leaf to physiological maturity of the bean plants. The International Center for Tropical Agriculture (CIAT) 1 to 9 scale was used to assess the disease in each sub plot, where 1 to 3 indicates none or sparse lesions; 4 to 6 indicates well-defined lesions but sparse; and 7 to 9 indicates many and well-defined lesions (Van Schoonhoven and Pastor-Corrales 1987). Disease severity ratings were used to calculate AUDPC for each subplot according to the formula used by Campbell and Madden 1990:

$$
\mathrm{AUDPC}=\sum_{i=1}^{n-1}\left(\frac{y_{i}+y_{i+1}}{2}\right)\left(t_{i+1}-t_{i}\right)
$$

where $t_{i}$ is time in days of each reading, $y_{i}$ is an assessment of the disease (proportion of infected leaves (at a 1 to 9 CIAT scale), and $n$ is the total number of observations made. Other foliar diseases of common bean such as anthracnose and leaf rust were observed but with very low levels of infection and were recorded as negligible. ALS is easily differentiated from other common foliar diseases due to its well-defined angular lesions characterized by fluffy sporulation on the underside of the foliage. Infected pods develop oval lesions with reddish-brown centers surrounded by darker colored margins.

Yield and yield component evaluations. Data were collected for plant height, number of plants per plot, number of pods per plant, and

Table 1. Analysis of variance for traits evaluated on five bean cultivars under different fungicide rates in ALS disease-prone environments of the Southern Highlands of Tanzania during the 2012/2013 and 2013/2014 heavy rains and light rains bean cropping seasons, respectively

\begin{tabular}{|c|c|c|c|c|c|c|c|c|c|}
\hline \multirow[b]{2}{*}{ Source of variation } & \multirow[b]{2}{*}{$\mathbf{d f}^{\mathbf{x}}$} & \multicolumn{2}{|c|}{$\mathbf{A U D P C}^{\mathbf{z}}$} & \multicolumn{2}{|c|}{ Pods per plant } & \multicolumn{2}{|c|}{100 seed weight } & \multicolumn{2}{|c|}{ Grain yield (kg/ha) } \\
\hline & & $\mathbf{M S}^{\mathbf{y}}$ & $\mathbf{P}>\mathbf{F}$ & MS & $\mathbf{P}>\mathbf{F}$ & MS & $\mathbf{P}>\mathbf{F}$ & MS & $\mathbf{P}>\mathbf{F}$ \\
\hline \multicolumn{10}{|c|}{ Experiment 1: 2012/2013 heavy rains } \\
\hline Replication & 5 & 50056 & $\ldots$ & 47.5 & $\ldots$ & 49.7 & $\ldots$ & 1263154 & $\ldots$ \\
\hline Fungicide & 2 & 77974 & 0.005 & 9.9 & 0.21 & 316.3 & 0.001 & 9188312 & 0.017 \\
\hline Error (a) & 10 & 8499 & $\ldots$ & 5.5 & $\ldots$ & 15.4 & & 1458771 & $\ldots$ \\
\hline Cultivars & 4 & 1941 & 0.139 & 2.2 & 0.86 & 265.6 & 0.001 & 244550 & 0.003 \\
\hline Fungicide $\times$ cultivars & 8 & 1814 & 0.120 & 6.4 & 0.49 & 10.4 & 0.963 & 148999 & 0.014 \\
\hline Error(b) & 60 & 1074 & $\ldots$ & 6.8 & $\ldots$ & 34.7 & $\ldots$ & 56000 & $\ldots$ \\
\hline Total & 89 & $\ldots$ & $\ldots$ & $\ldots$ & $\ldots$ & $\ldots$ & $\ldots$ & $\ldots$ & $\ldots$ \\
\hline \multicolumn{10}{|c|}{ Experiment 2: 2012/2013 light rains } \\
\hline Replication & 5 & 38150 & $\ldots$ & 8.41 & $\ldots$ & 248.2 & $\ldots$ & 1270330 & $\cdots$ \\
\hline Fungicide & 2 & 205874 & 0.001 & 30.14 & 0.03 & 18.3 & 0.017 & 307712 & 0.035 \\
\hline Error (a) & 10 & 5662.0 & $\ldots$ & $\ldots$ & $\ldots$ & 8.6 & $\ldots$ & 64060 & $\ldots$ \\
\hline Cultivars & 4 & 1282.0 & 0.426 & 2.61 & 0.53 & 446.3 & 0.001 & 80154 & 0.053 \\
\hline Fungicide $\times$ cultivar & 8 & 584.0 & 0.450 & 3.10 & 0.49 & 15.6 & 0.963 & 66712 & 0.723 \\
\hline Error(b) & 60 & 1309.0 & $\ldots$ & 3.30 & $\ldots$ & 40.9 & $\ldots$ & 100836 & $\ldots$ \\
\hline Total & 89 & $\ldots$ & $\ldots$ & $\ldots$ & $\ldots$ & $\ldots$ & $\ldots$ & $\ldots$ & $\ldots$ \\
\hline \multicolumn{10}{|c|}{ Experiment 3: 2013/2014 heavy rains } \\
\hline Replication & 5 & 4743.8 & $\ldots$ & 17.79 & $\ldots$ & 2.86 & $\ldots$ & 5620 & $\ldots$ \\
\hline Fungicide & 2 & 278921.1 & 0.001 & 160.67 & 0.001 & 944.90 & 0.001 & 13301731 & 0.001 \\
\hline Error (a) & 10 & 727.1 & $\ldots$ & 5.69 & $\ldots$ & 3.94 & $\ldots$ & 11713 & $\ldots$ \\
\hline Cultivars & 4 & 3960.0 & 0.001 & 11.29 & 0.001 & 21.70 & 0.002 & 148730 & 0.023 \\
\hline Fungicide $\times$ cultivar & 8 & 302.7 & 0.901 & 1.55 & 0.692 & 6.56 & 0.184 & 57885 & 0.319 \\
\hline Error(b) & 60 & 712.0 & $\cdots$ & 2.22 & $\cdots$ & 4.43 & $\cdots$ & 4854 & $\cdots$ \\
\hline Total & 89 & $\cdots$ & $\cdots$ & $\cdots$ & $\cdots$ & $\cdots$ & $\cdots$ & $\cdots$ & $\cdots$ \\
\hline \multicolumn{10}{|c|}{ Experiment 4: 2013/2014 light rains } \\
\hline Replication & 5 & 1902.4 & $\ldots$ & 19.00 & $\ldots$ & 762.4 & $\cdots$ & 567760 & $\cdots$ \\
\hline Fungicide & 2 & 39087.8 & 0.001 & 5.34 & 0.44 & 262.9 & 0.001 & 1326833 & 0.002 \\
\hline Error (a) & 10 & 952.8 & $\ldots$ & 6.02 & $\ldots$ & 14.4 & $\ldots$ & 101213 & $\ldots$ \\
\hline Cultivars & 4 & 1119.7 & 0.040 & 12.90 & 0.014 & 841.1 & 0.001 & 469887 & 0.001 \\
\hline Fungicide $\times$ cultivar & 8 & 718.7 & 0.133 & 1.74 & 0.870 & 11.3 & 0.160 & 52906 & 0.760 \\
\hline Error(b) & 60 & 438.2 & $\ldots$ & 3.80 & $\ldots$ & 7.4 & $\ldots$ & 85834 & $\ldots$ \\
\hline Total & 89 & $\ldots$ & $\ldots$ & $\ldots$ & $\ldots$ & $\ldots$ & $\ldots$ & $\ldots$ & $\ldots$ \\
\hline
\end{tabular}

${ }^{\mathrm{x}} \mathrm{df}=$ degrees of freedom

${ }^{\mathrm{y}} \mathrm{MS}=$ mean square.

${ }^{\mathrm{z}}$ AUDPC $=$ area under disease progressive curve. 
number of seeds per pod for each sub plot. Plant height was measured in centimeters from ground level to the top of the canopy. At maturity all plots were harvested and the seeds were cleaned to remove all unwanted materials such as plant debris and soil and then weighed. Yield from each plot was determined without removing shriveled or discolored seed. Hundred seed weight was taken for each plot and recorded in grams. Thereafter, the diseased seeds were sorted out and clean seed was expressed in kilograms per hectare.

Economics of yield losses. Yield losses or gains were determined on market-valued seed to estimate the total returns or losses in United States dollars (USD). The price of a tin $(20 \mathrm{~kg})$ of beans was obtained from the local markets where the five cultivars were sold. Total costs of production (labor, fertilizers, fungicide applications, fungicide, weeding, and harvesting) were determined and recorded on a hectare basis. Calculations were not performed on untreated plots. The untreated plots were left to avoid creating a huge difference in the results when compared with the treated plots.

Data analysis. The AUDPC was calculated for each cultivar using the Microsoft excel program. Analysis of variance was performed on AUDPC, yield, and yield components using Genstat software version 14.1 (Payne et al. 2011). Fisher's least significant difference test was used to separate treatment means at $P \leq 0.05$. Correlation analysis was done for combined means over replicates and the cropping season to examine the relationship between disease (AUDPC) and yield data. Percentage yield loss was calculated for each cultivar using the following:

$$
\begin{aligned}
& \text { Yield loss }=[(\mathrm{YSP}-\mathrm{YNF}) / \mathrm{YSP}] \times 100 \\
& \text { Yield loss }=[(\mathrm{YSP}-\mathrm{YFP}) / \mathrm{YSP}] \times 100
\end{aligned}
$$

where YSP is yields obtained from plots sprayed with fungicide at the recommended rates, YFP is yields obtained from plots sprayed with fungicide at farmers' rates, and YNFs is yield obtained from unsprayed plots.

Cost-benefit analysis was done and marginal rate of return (MRR) was calculated for the market-valued seed using the partial budget analysis method (Katungi et al. 2011). The following formula was used to calculate marginal rate of return (MRR):

$$
\mathrm{MRR}=\left(\mathrm{NB}_{2}-\mathrm{NB}_{1}\right) /\left(\mathrm{TVC}_{2}-\mathrm{TVC}_{1}\right)
$$

where $\mathrm{MRR}=$ marginal rate of return, $\mathrm{NB}_{1}=$ net benefit after using farmers' rate of fungicide, $\mathrm{NB}_{2}=$ net benefit for using fungicide at the

\begin{tabular}{|c|c|c|c|c|c|c|c|c|c|}
\hline \multirow[b]{2}{*}{$\begin{array}{l}\text { Fungicide applications } \\
\text { rates }\end{array}$} & \multirow[b]{2}{*}{ Cultivars } & \multicolumn{4}{|c|}{$2012 / 2013$ heavy rain season } & \multicolumn{4}{|c|}{$2012 / 2013$ light rain season } \\
\hline & & AUDPC $^{\mathbf{y}}$ & $\begin{array}{l}\text { Pods per } \\
\text { plant }\end{array}$ & $\begin{array}{c}\text { Seed } \\
\text { weight }\end{array}$ & $\begin{array}{c}\text { Grain yield } \\
\text { (kg/ha) }\end{array}$ & AUDPC & $\begin{array}{c}\text { Pods per } \\
\text { plant }\end{array}$ & $\begin{array}{c}\text { Seed } \\
\text { weight }\end{array}$ & $\begin{array}{c}\text { Grain yield } \\
\text { (kg/ha) }\end{array}$ \\
\hline \multirow[t]{5}{*}{ None } & Kigoma & $255.0 \mathrm{ab}^{\mathrm{z}}$ & $11.8 \mathrm{ab}$ & 34.7 ef & 1223 ghij & $254.2 \mathrm{a}$ & $10.2 \mathrm{~cd}$ & 29.9 ef & $1861 \mathrm{~d}$ \\
\hline & Kablanketi & $262.5 \mathrm{ab}$ & $12.5 \mathrm{ab}$ & $33.9 \mathrm{f}$ & 1517 efghi & $230.0 \mathrm{ab}$ & $10.6 \mathrm{bc}$ & $28.5 \mathrm{e}$ & $1887 \mathrm{~cd}$ \\
\hline & Maini & $245.8 \mathrm{ab}$ & $13.7 \mathrm{ab}$ & $34.3 \mathrm{f}$ & 1389 fghij & $230.8 \mathrm{ab}$ & $9.6 \mathrm{~d}$ & $29.6 \mathrm{ef}$ & 1919 bc \\
\hline & Uyole 94 & $226.7 \mathrm{abc}$ & $11.3 \mathrm{~b}$ & $43.1 \mathrm{abcd}$ & $1847 \mathrm{bcd}$ & $251.7 \mathrm{a}$ & $9.7 \mathrm{~d}$ & $41.3 \mathrm{a}$ & $1956 \mathrm{bc}$ \\
\hline & Uyole 96 & $205.0 \mathrm{bc}$ & $12.3 \mathrm{ab}$ & $44.1 \mathrm{abc}$ & 1656 bcde & $226.7 \mathrm{ab}$ & $10.7 \mathrm{bc}$ & $39.9 \mathrm{~cd}$ & $2005 \mathrm{ab}$ \\
\hline \multirow[t]{5}{*}{ Farmers' practice } & Kigoma & $263.3 \mathrm{a}$ & $13.6 \mathrm{ab}$ & 34.7 ef & 1631 bcde & $225.0 \mathrm{ab}$ & $10.7 \mathrm{bc}$ & $33.2 \mathrm{de}$ & $2042 \mathrm{ab}$ \\
\hline & Kablanketi & $219.2 \mathrm{bc}$ & $14.2 \mathrm{a}$ & 36.7 def & 1467 efgh & $207.5 \mathrm{bc}$ & $9.5 \mathrm{~d}$ & 30.3 ef & $2203 \mathrm{ab}$ \\
\hline & Maini & $223.3 \mathrm{bc}$ & $11.5 \mathrm{~b}$ & 38.0 cdef & 1467 efgh & $233.3 \mathrm{ab}$ & $10.6 \mathrm{bc}$ & $31.5 \mathrm{de}$ & $1868 \mathrm{~d}$ \\
\hline & Uyole 94 & $237.5 \mathrm{abc}$ & $13.8 \mathrm{ab}$ & $42.1 \mathrm{abcd}$ & 1572 efgh & $237.5 \mathrm{ab}$ & $10.5 \mathrm{bc}$ & $41.5 \mathrm{a}$ & $2196 \mathrm{ab}$ \\
\hline & Uyole 96 & $223.3 \mathrm{bc}$ & $12.2 \mathrm{ab}$ & $42.2 \mathrm{abcd}$ & $1678 \mathrm{bcde}$ & $225.0 \mathrm{ab}$ & $11.0 \mathrm{bc}$ & $40.6 \mathrm{ab}$ & $2053 \mathrm{ab}$ \\
\hline \multirow[t]{5}{*}{ Recommended } & Kigoma & $145.0 \mathrm{de}$ & $13.3 \mathrm{ab}$ & $41.0 \mathrm{bcde}$ & $2411 b c$ & $87.5 \mathrm{de}$ & $13.3 \mathrm{a}$ & $35.5 \mathrm{cde}$ & $2272 \mathrm{a}$ \\
\hline & Kablanketi & $155.0 \mathrm{de}$ & $13.3 \mathrm{ab}$ & $42.0 \mathrm{abcd}$ & $2486 \mathrm{bc}$ & $90.8 \mathrm{~cd}$ & $11.0 \mathrm{bc}$ & 29.8 ef & $2084 \mathrm{ab}$ \\
\hline & Maini & $146.7 \mathrm{de}$ & $14.5 \mathrm{a}$ & $41.6 \mathrm{abcd}$ & $2514 \mathrm{ab}$ & $90.0 \mathrm{~cd}$ & $11.6 \mathrm{bc}$ & $32.0 \mathrm{de}$ & $2122 \mathrm{ab}$ \\
\hline & Uyole 94 & $137.5 \mathrm{e}$ & $13.3 \mathrm{ab}$ & $46.8 \mathrm{ab}$ & 2472 bc & $92.5 \mathrm{cde}$ & $12.6 \mathrm{ab}$ & $38.4 \mathrm{bc}$ & $2073 \mathrm{ab}$ \\
\hline & Uyole 96 & $155.0 \mathrm{de}$ & $12.8 \mathrm{ab}$ & $48.3 \mathrm{a}$ & $2775 \mathrm{a}$ & $79.2 \mathrm{e}$ & $11.5 \mathrm{bc}$ & $39.0 \mathrm{bc}$ & $2048 \mathrm{ab}$ \\
\hline
\end{tabular}
recommended rates, and $\mathrm{TVC}_{1}$ (total variable costs) for treatment one

Table 2. Fungicide treatment means by cultivar for agronomic traits evaluated during 2012/2013 cropping seasons

${ }^{y}$ AUDPC $=$ area under disease progressive curve.

\begin{tabular}{|c|c|c|c|c|c|c|c|c|c|}
\hline \multirow[b]{2}{*}{$\begin{array}{l}\text { Fungicide applications } \\
\text { rates }\end{array}$} & \multirow[b]{2}{*}{ Cultivars } & \multicolumn{4}{|c|}{$2013 / 2014$ heavy rain season } & \multicolumn{4}{|c|}{$2013 / 2014$ light rain season } \\
\hline & & AUDPC $^{\mathbf{y}}$ & $\begin{array}{l}\text { Pods per } \\
\text { plant }\end{array}$ & $\begin{array}{c}\text { Seed } \\
\text { weight }\end{array}$ & $\begin{array}{l}\text { Grain yield } \\
(\mathrm{kg} / \mathrm{ha})\end{array}$ & AUDPC & $\begin{array}{l}\text { Pods per } \\
\text { plant }\end{array}$ & $\begin{array}{c}\text { Seed } \\
\text { weight }\end{array}$ & $\begin{array}{c}\text { Grain yield } \\
(\mathrm{kg} / \mathrm{ha})\end{array}$ \\
\hline \multirow[t]{5}{*}{ None } & Kigoma & $282.5 \mathrm{a}^{\mathrm{z}}$ & $10.2 \mathrm{fg}$ & $35.0 \mathrm{cde}$ & $972 \mathrm{e}$ & $155.8 \mathrm{a}$ & $12.0 \mathrm{bc}$ & $38.1 \mathrm{fg}$ & 1989 de \\
\hline & Kablanketi & $239.2 \mathrm{bcd}$ & $10.2 \mathrm{fg}$ & $37.7 \mathrm{~b}$ & $1147 \mathrm{cde}$ & $130.0 \mathrm{bc}$ & $12.5 \mathrm{ab}$ & $42.1 \mathrm{e}$ & $1892 \mathrm{de}$ \\
\hline & Maini & $253.3 \mathrm{abc}$ & $9.2 \mathrm{~g}$ & $36.3 \mathrm{bc}$ & $1231 \mathrm{bcd}$ & $153.3 \mathrm{ab}$ & $10.8 \mathrm{~cd}$ & $36.2 \mathrm{~g}$ & 1984 de \\
\hline & Uyole 94 & $242.5 \mathrm{bc}$ & $11.2 \mathrm{ef}$ & 34.2 cde & $1369 \mathrm{bc}$ & $139.2 \mathrm{abc}$ & $11.6 \mathrm{abc}$ & $52.2 \mathrm{bcd}$ & 1975 cde \\
\hline & Uyole 96 & $245.8 \mathrm{bc}$ & 10.6 efg & $32.6 \mathrm{e}$ & $1450 \mathrm{~b}$ & $148.3 \mathrm{abc}$ & $12.5 \mathrm{ab}$ & $51.1 \mathrm{~cd}$ & 2178 abcd \\
\hline \multirow[t]{5}{*}{ Farmers' practice } & Kigoma & $265.8 \mathrm{ab}$ & $10.5 \mathrm{efg}$ & 34.7 cde & $1111 \mathrm{de}$ & $151.7 \mathrm{ab}$ & $11.2 \mathrm{bc}$ & $41.5 \mathrm{e}$ & $1728 \mathrm{e}$ \\
\hline & Kablanketi & $211.7 \mathrm{~d}$ & $10.3 \mathrm{fg}$ & 34.5 cde & $1111 \mathrm{de}$ & $134.2 \mathrm{abc}$ & $11.2 \mathrm{bc}$ & $42.4 \mathrm{e}$ & $2056 \mathrm{de}$ \\
\hline & Maini & $234.2 \mathrm{~cd}$ & $10.3 \mathrm{fg}$ & $36.2 \mathrm{bcd}$ & 1194 cde & $123.3 \mathrm{c}$ & $10.3 \mathrm{~cd}$ & $40.7 \mathrm{ef}$ & $2323 \mathrm{ab}$ \\
\hline & Uyole 94 & $235.0 \mathrm{~cd}$ & $12.2 \mathrm{de}$ & $32.8 \mathrm{e}$ & $1222 \mathrm{bcd}$ & $145.0 \mathrm{abc}$ & $11.2 \mathrm{bc}$ & $52.8 \mathrm{bc}$ & $2068 \mathrm{bcd}$ \\
\hline & Uyole 96 & $230.0 \mathrm{~cd}$ & $11.3 \mathrm{ef}$ & $33.9 \mathrm{de}$ & $1278 \mathrm{bcd}$ & $134.2 \mathrm{abc}$ & $13.5 \mathrm{a}$ & $54.1 \mathrm{bc}$ & $2150 \mathrm{abcd}$ \\
\hline \multirow{5}{*}{ Recommended } & Kigoma & $91.7 \mathrm{e}$ & $13.3 \mathrm{~cd}$ & $45.1 \mathrm{a}$ & $2375 \mathrm{ab}$ & $95.0 \mathrm{~d}$ & $11.3 \mathrm{bc}$ & $42.4 \mathrm{e}$ & $2648 \mathrm{a}$ \\
\hline & Kablanketi & $69.2 \mathrm{ef}$ & $15.0 \mathrm{abc}$ & $45.6 \mathrm{a}$ & $2306 \mathrm{ab}$ & $84.2 \mathrm{def}$ & $11.2 \mathrm{bc}$ & $49.1 \mathrm{~d}$ & $2552 \mathrm{ab}$ \\
\hline & Maini & $72.5 \mathrm{e}$ & $13.5 \mathrm{bcd}$ & $44.2 \mathrm{ab}$ & $2417 \mathrm{a}$ & $87.5 \mathrm{de}$ & $9.6 \mathrm{c}$ & $44.1 \mathrm{e}$ & $2477 \mathrm{abc}$ \\
\hline & Uyole 94 & $79.2 \mathrm{e}$ & $15.2 \mathrm{ab}$ & $43.8 \mathrm{ab}$ & $2292 \mathrm{ab}$ & $68.3 \mathrm{ef}$ & $11.7 \mathrm{bc}$ & $55.6 \mathrm{ab}$ & $2387 \mathrm{abc}$ \\
\hline & Uyole 96 & $75.8 \mathrm{e}$ & $15.8 \mathrm{a}$ & $44.1 \mathrm{ab}$ & $2417 \mathrm{a}$ & $61.7 \mathrm{f}$ & $11.6 \mathrm{bc}$ & $57.8 \mathrm{a}$ & $2419 a b c$ \\
\hline
\end{tabular}

${ }^{\mathrm{z}}$ Means followed by the same letter within a column are not significantly different according to Fisher's least significant difference test at $P<0.05$.

Table 3. Fungicide treatment means by cultivars for the agronomic traits evaluated during 2013/2014 bean cropping seasons

y AUDPC $=$ area under disease progressive curve.

${ }^{\mathrm{z}}$ Means followed by the same letter in a column are not significantly different according to Fisher's least significant difference test at $P<0.05$. 
and $\mathrm{TVC}_{2}$ was the total variable costs associated with the usage of treatment.

\section{Results}

Analyses of variance are presented in Table 1 . The $F$ value for the fungicide $\times$ cultivar interactions was significant $(P \leq 0.05)$ only for yield during the 2012/2013 rainy season indicating that fungicide performance did not depend on the type of cultivar grown or the season in which they were planted. On the other hand, the effect of fungicide was consistently significant at $P \leq 0.05$ for AUDPC, seed weight, and grain yield for all the years in which the trials were conducted. Significant differences were also observed for the number of pods per plant in 2012/2013 light rains and in 2013/2014 heavy rains. Significant differences between cultivars were also observed particularly for seed weight and yield (Table 1).

Mean comparisons of fungicide by cultivars are presented in Tables 2 and 3. Angular leaf spot was severe in nonsprayed plots for all trials, but more so during heavy rains. A comparison of fungicide treatment means indicated that plots sprayed with "Othello TOP" at recommended rates of $400 \mathrm{ml} / \mathrm{ha}$ had the lowest scores for AUDPC, higher numbers of pods per plant, increased seed weight, and yield compared with unsprayed and those sprayed following farmers' application rates. The mean number of pods per plant varied between fungicide treatments for all seasons in which the five cultivars were evaluated (Table 2). Seed weight and yield differed between cultivars, and the differences were maintained across seasons regardless of whether the rates of fungicide applied were those recommended or farmers' practice. In all four bean cropping seasons in which the

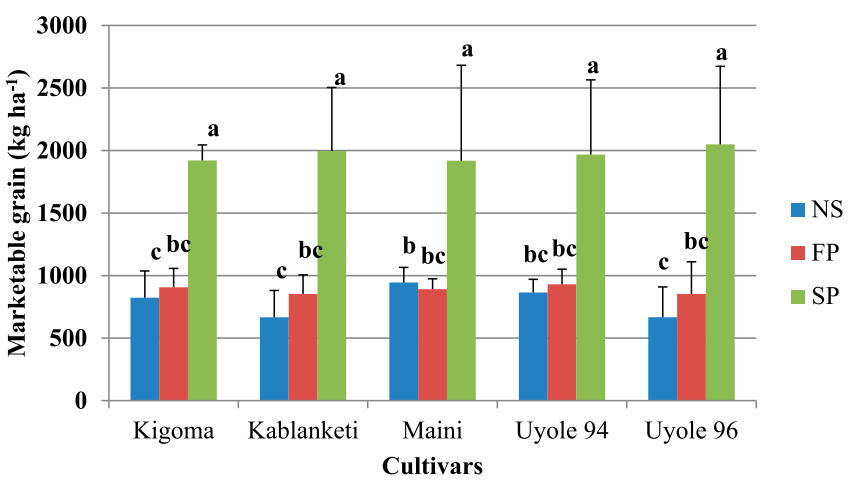

Fig. 1. Mean marketable seed obtained during heavy rains in 2012/2013 and 2013/ 2014. NS = not sprayed; FP = farmers' practice in which plots were sprayed once at the later stage of crop development (R4) with $50 \mathrm{ml}$ of Othello TOP; SP = fungicide-sprayed plots at the recommended rates of $400 \mathrm{ml}$ of Othello TOP per hectare. Error bars represent standard deviation of means at $P \leq 0.05$. Different letters denote significant differences between treatments.

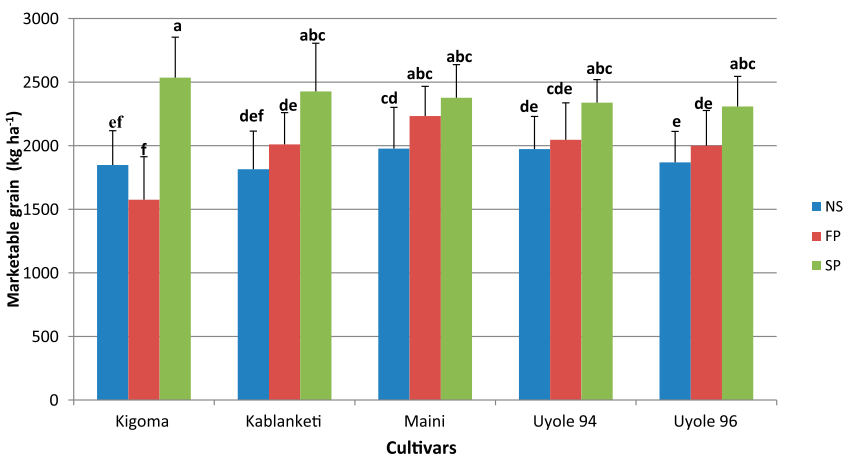

Fig. 2. Mean marketable seed obtained during light rains in 2012/2013 and 2013/2014. $\mathrm{NS}=$ not sprayed; $\mathrm{FP}=$ farmers' practice in which plots were sprayed once at the later stage of crop development (R4) with $50 \mathrm{ml}$ of Othello TOP; SP = fungicide-sprayed plots at the recommended rates of $400 \mathrm{ml}$ of Othello TOP per ha. Error bars represent standard error of means at $P \leq 0.05$. Letters of the same type denote nonsignificant differences between treatments. trials were conducted, higher yields were consistently obtained during light rains compared with heavy rains.

When the harvested crop was sorted into market-value seed, plots sprayed with the recommended rates during heavy and light rains showed higher yields compared with the unsprayed and farmers' practice (Fig. 1, 2). Shriveled and discolored seed were more prevalent in unsprayed plots for all five cultivars evaluated. High yield losses that ranged from 44.2 to $57 \%$ and 39 to $61 \%$ were obtained during heavy rains under farmers' practice and no treatment, respectively. However, lower yield losses ranging from 6.1 to $37.8 \%$ and 6.0 to $25 \%$ occurred during light rains under farmers' practice and no treatment, respectively (Table 4).

ALS disease severity. Correlations among AUDPC pods per plant, hundred seed weight, market-value seed, and yield were highly significant and negative during heavy rains. However, the relationship between pods per plant and yield was weak, although the value obtained was significant (Table 5). As the AUDPC increased, the number of pods per plant, 100 seed weight, market-value seed, and yield decreased as indicated by high, negatively correlated values. However, the market-value seed was strongly and positively correlated with grain yield regardless of the season in which the cultivars were evaluated (Table 5).

Economic analysis. The cost-benefit analyses for the treatments used in this experiment are presented in Table 6 and 7 . The total variable costs and the total returns increased with the recommended fungicide treatments of $400 \mathrm{ml} / \mathrm{ha}$.

The trend of benefits produced when cultivars were subjected to the three treatments was consistent during heavy and light rains. However, during light rains there were higher yields in plots sprayed following farmers' practice and nonsprayed plots compared with those obtained during heavy rains. The average net benefit of all treatments during heavy rains was USD \$620/ha with a range of $\$ 284$ to 1041/ha while during light rains the mean was $\$ 1169 /$ ha and the range was $\$ 846$ to $1410 /$ ha. Based on the net benefit, 'Kigoma' had higher benefits (\$1410.25) followed by 'Kablanketi' (\$1340.05). High marginal rates of return (MRR) were obtained with 'Kablanketi' (\$11.50) during heavy rains followed by 'Maini' $(\$ 10.25)$. It is worth noting that the prices used were current during the study

Table 4. Percentage yield losses comparing data collected during the heavy and light rains in the Southern Highlands of Tanzania

\begin{tabular}{llcccr}
\hline & \multicolumn{2}{c}{$\begin{array}{c}\text { Heavy rains } \\
\text { yield loss }\end{array}$} & & \multicolumn{2}{c}{$\begin{array}{c}\text { Light rains \% yield } \\
\text { loss }\end{array}$} \\
\cline { 2 - 5 } Cultivars & FPy & NSz $^{\mathbf{z}}$ & & FP & NS \\
\hline Kigoma & 48.6 & 49.5 & 37.8 & 27.1 \\
Kablanketi & 57.4 & 61.0 & & 17.1 & 25.2 \\
Maini & 50.2 & 47.5 & 6.1 & 16.8 \\
Uyole 94 & 44.2 & 39.9 & & 12.4 & 15.6 \\
Uyole 96 & 44.7 & 45.6 & 2.4 & 6.0 \\
\hline
\end{tabular}

y $\mathrm{FP}=$ farmers' practice in which plots were sprayed once at the later stage of crop development $(\mathrm{R} 4=$ mid-pod setting where $50 \%$ of pods are at maximum length) with $50 \mathrm{ml}$ of Othello TOP.

${ }^{\mathrm{z}} \mathrm{NS}=$ plots not sprayed with fungicide.

Table 5. Correlations between AUDPC yield and yield components during the 2012/2013 and 2013/2014 heavy rains ${ }^{y}$

\begin{tabular}{llllll}
\hline \multirow{2}{*}{$\begin{array}{l}\text { Heavy } \\
\text { rains }\end{array}$} & \multicolumn{5}{c}{ Light rains } \\
\cline { 2 - 6 } & AUDPC & \multicolumn{1}{c}{ POP } & HSW & \multicolumn{1}{c}{ MVS } & \multicolumn{1}{c}{ GY } \\
\hline AUDPC & 1 & -0.0457 & -0.0681 & -0.3967 & -0.2475 \\
POP & $-0.3565^{* * z}$ & 1 & $0.2810^{*}$ & 0.154 & $0.5115^{* *}$ \\
HSW & $-0.7290^{* *}$ & $0.1890^{*}$ & 1 & $0.5115^{* *}$ & 0.1748 \\
MVS & $-0.8968^{* *}$ & $0.3889 * *$ & $0.7462^{* *}$ & 1 & $0.6606 * *$ \\
GY & $-0.8730^{* *}$ & $0.3531 * *$ & $0.7181 * *$ & $0.9788^{* *}$ & 1 \\
\hline
\end{tabular}

${ }^{y}$ AUDPC $=$ area under disease progressive curve; $\mathrm{POP}=$ pods per plant; $\mathrm{HSW}=$ hundred seed weight; MVS = market valued seed; GY = grain yield

$\mathrm{z} *=$ significant at $P \leq 0.05 ; * *=$ significant at $P \leq 0.001$. 
period. Common bean prices in the SHT depend on the crop's supply and demand in the market.

The MRR indicating investment and recovery of the money was high when the recommended fungicide rate of $400 \mathrm{ml} / \mathrm{ha}$ was applied four times. Differences in MRR were apparent between heavy and light rain seasons. Cultivar Maini showed the lowest MMR with a negative value under farmers' practice of applying fungicide during heavy rains, whereas losses in investment occurred with 'Kigoma' under farmers' practice during light rains (Table 6,7).

\section{Discussion}

This study revealed that $P$. griseola caused significant disease during heavy rains that were characterized by mild temperatures (17 to $24^{\circ} \mathrm{C}$ ) and high relative humidity (95\%). These conditions have been reported to support the pathogen's ability to infect, germinate, and subsequently sporulate on susceptible cultivars (Celetti et al. 2005; Monda et al. 2001). We report here high values for AUDPC particularly with 'Kigoma' and 'Kablanketi' receiving no fungicides during heavy rains. However, lower AUDPC values occurred with the same cultivars during light rains where temperatures were higher and leaf wetness duration was shorter.

Fungicide applied at the recommended rates of $400 \mathrm{ml} / \mathrm{ha}$ allowed the crop to attain physiological maturity with minimal disease occurrence. On the other hand, fungicide applied following farmers' practice did not significantly reduce ALS as the rates were low and the application was too late. As a result, seed from infected plants were of poor quality, discolored, and shriveled with low market value. Seed yield in common bean is determined by yield components that include pods per plant, seeds per pod, and seed weight. Photosynthesis is necessary for good seed weight and foliar diseases such as ALS results in underweight seed (Celetti et al. 2005). Necrosis and defoliation caused by $P$. griseola on unsprayed plants would have less chlorophyll and thus lower respiration and less carbon assimilation. Reductions in chlorophyll and consequently lowering carbon assimilation have been reported on bean plants infected with angular leaf spot disease (Bassanezi et al. 2002).

Although common bean is one of the major and basic foods in the SHT, growing beans during heavy rains without any control measures will result in losses of more than $50 \%$, especially to 'Kablanketi' which is highly preferred. Small farm holders in the SHT recycle seed from season to season with little understanding of the importance of seedborne diseases. In this regard, seed resulting from the heavy rainy season is likely to be contaminated with $P$. griseola, resulting in significant disease occurrence in the following planting. This is considered one of the primary reasons why ALS is on the rise in the SHT and bean production is going down. Unfortunately, a majority of the population depends on beans as a major source of protein.

The relationships between the AUDPC, seed weights, and yield were similar in that all showed negative associations with ALS, suggesting the necessity of optimizing disease management practices to

Table 6. Economic analysis of marketable seed by fungicide treatment during the 2012/1013 and 2013/2014 heavy rains

\begin{tabular}{|c|c|c|c|c|c|c|}
\hline Cultivars & Fungicide treatment ${ }^{y}$ & Grain yield (kg/ha) & Costs that vary (USD) & Gross farm benefit (USD) & Net benefit (USD) & MRR $^{\mathbf{z}}$ \\
\hline Kigoma & NS & 823 & 150.00 & 534.95 & 384.95 & $\ldots$ \\
\hline Kigoma & FP & 906 & 178.12 & 588.90 & 410.78 & 0.91 \\
\hline Kigoma & SP & 1921 & 237.50 & 1248.65 & 1011.15 & 10.11 \\
\hline Kablanketi & NS & 667 & 150.00 & 433.55 & 283.55 & $\ldots$ \\
\hline Kablanketi & FP & 854 & 178.12 & 555.10 & 376.98 & 3.32 \\
\hline Kablanketi & SP & 1996 & 237.50 & 1297.40 & 1059.9 & 11.50 \\
\hline Maini & NS & 945 & 150.00 & 614.25 & 464.25 & $\ldots$ \\
\hline Maini & FP & 891 & 178.12 & 579.15 & 401.03 & -2.25 \\
\hline Maini & SP & 1919 & 237.50 & 1247.35 & 1009.85 & 10.25 \\
\hline Uyole 94 & NS & 865 & 150.00 & 562.25 & 412.25 & $\ldots$ \\
\hline Uyole 94 & FP & 931 & 178.12 & 605.15 & 427.03 & 0.53 \\
\hline Uyole 94 & SP & 1967 & 237.50 & 1278.55 & 1041.05 & 10.34 \\
\hline Uyole 96 & NS & 938 & 150.00 & 609.70 & 459.70 & $\ldots$ \\
\hline Uyole 96 & FP & 1000 & 178.12 & 650.00 & 471.88 & 0.43 \\
\hline Uyole 96 & SP & 2054 & 237.50 & 1335.10 & 1097.6 & 10.53 \\
\hline
\end{tabular}

${ }^{\mathrm{y}} \mathrm{SP}=$ plots sprayed with fungicide at the recommended rates of $400 \mathrm{ml} / \mathrm{ha}$; $\mathrm{FP}=$ farmers' practice in which plots were sprayed once at the later stage of crop development (R4 = mid-pod setting where $50 \%$ of pods are at maximum length) with $50 \mathrm{ml}$ of Othello TOP; NS = plots not sprayed with fungicide ${ }^{\mathrm{z}} \mathrm{MRR}=$ marginal rate of return.

Table 7. Economic analysis of market-valuable seed by fungicide treatment during the 2012/1013 and 2013/2014 light rains

\begin{tabular}{|c|c|c|c|c|c|c|}
\hline Cultivars & Fungicide treatment ${ }^{y}$ & Grain yield (kg/ha) & Costs that vary (USD) & Gross farm benefit (USD) & Net benefit (USD) & $\operatorname{MRR}^{\mathbf{z}}$ \\
\hline Kigoma & NS & 1848 & 150.00 & 1201.20 & 1051.20 & $\ldots$ \\
\hline Kigoma & FP & 1575 & 178.12 & 1023.75 & 845.63 & -12.6 \\
\hline Kigoma & SP & 2535 & 237.50 & 1647.75 & 1410.25 & 9.51 \\
\hline Kablanketi & NS & 1815 & 150.00 & 1179.75 & 1029.75 & $\ldots$ \\
\hline Kablanketi & $\mathrm{FP}$ & 2010 & 178.12 & 1306.5 & 1128.38 & 3.51 \\
\hline Kablanketi & SP & 2427 & 237.50 & 1577.55 & 1340.05 & 3.56 \\
\hline Maini & NS & 1977 & 150.00 & 1285.05 & 1135.05 & $\ldots$ \\
\hline Maini & $\mathrm{FP}$ & 2233 & 178.12 & 1451.45 & 1273.33 & 4.92 \\
\hline Maini & SP & 2377 & 237.50 & 1545.05 & 1307.55 & 1.21 \\
\hline Uyole 94 & NS & 1973 & 150.00 & 1282.45 & 1132.45 & $\ldots$ \\
\hline Uyole 94 & $\mathrm{FP}$ & 2046 & 178.12 & 1329.9 & 1151.78 & 0.33 \\
\hline Uyole 94 & SP & 2338 & 237.5 & 1519.7 & 1282.2 & 2.19 \\
\hline Uyole 96 & NS & 1869 & 150.00 & 1214.85 & 1064.85 & $\ldots$ \\
\hline Uyole 96 & $\mathrm{FP}$ & 2000 & 178.12 & 1300.00 & 1121.88 & 2.02 \\
\hline Uyole 96 & SP & 2308 & 237.50 & 1500.20 & 1262.70 & 2.37 \\
\hline
\end{tabular}

y SP = plots sprayed with fungicide at the recommended rates of $400 \mathrm{ml} / \mathrm{ha}$; FP = farmers' practice in which plots were sprayed once at the later stage of crop development $(\mathrm{R} 4=$ mid-pod setting where $50 \%$ of pods are at maximum length) with 50 ml of Othello TOP; NS = plots not sprayed with fungicide.

${ }^{\mathrm{z}} \mathrm{MRR}=$ marginal rate of return. 
reduce infections, particularly during heavy rains. Although the same trend was observed during light rains, the association was not significant, probably because of lower disease pressure caused by weather conditions in those seasons.

Economic analysis revealed high returns in plots sprayed with fungicide at the recommended rates of $400 \mathrm{ml} / \mathrm{ha}$. For every U.S. dollar invested, it was recovered with the additional profit of $\$ 11.50$ for 'Kablanketi' and \$10.25 for 'Maini' from shifting from no fungicide spray and farmers' practice types of ALS disease management to applying recommended rates of $400 \mathrm{ml} / \mathrm{ha}$ of the fungicide. Following farmers' practice of a reduced rate of fungicide applied late in the season, the dollar invested was lost for 'Maini' and 'Kigoma' was lost with the MRR of -2.25 and -12.6 for 'Maini during heavy rains and 'Kigoma' during light rains. A treatment is considered a worthy investment by the farmer if the MRR is higher than the minimal acceptable rate of return of $100 \%$ (CIMMYT 1998). Therefore, in the SHT, the current farmers' fungicide practices are not economical at least regarding 'Kigoma', 'Uyole 94', 'Uyole 96', and 'Maini'. Consequently, a farmer will gain little if fungicides are sprayed on cultivars Kablanketi, Kigoma, Maini, Uyole 94, and Uyole 96 during light rains. It has been shown that, when disease severity is low and there is minimal yield loss, applying fungicides will not result in either yield or economic advantage when individual variety is considered (McGrath 2013).

The findings of this study indicate that the application of fungicides when beans are grown during heavy rains is necessary to sustain crop quality and yields in the SHT. During the light rain period, farmers may gain little if fungicides are applied. Education of farmers regarding the nature of seedborne disease and the proper use of fungicide to reduce losses caused by ALS in beans is necessary. Consequently, resistance breeding against $P$. griseola would be ideal for long-term management of ALS, an important disease of common bean in the SHT.

\section{Literature Cited}

Bassanezi, R. B., Amorim, L., Bergamin-Filho, A., and Berger, R. D. 2002. Gas exchange and emissions. Of chlorophyll fluorescence during the monocycle of rust, angular leaf spot and anthracnose of bean leaves as a function of their trophic characteristics. Phytopathology 150:37-47.

Bourgeois, G., Boote, K. J., and Berger, R. D. 1991. Growth, development, yield, and seed quality of Florunner peanut affected by late leaf spot. Peanut Sci. 18:137-143.

Campbell and Madden. 1990. Introduction to plant disease and epidemiology. John Wiley \& Sons. New York

Cardona-Alvarez, C., and Walker, J. C. 1956. Angular leaf spot of common bean. Phytopathology 46:610-615.

Celetti, M. J., Melzer, M. S., and Boland, G. J. 2005. Integrated management of Angular leaf spot (Phaeoisariopsis griseola (Sacc.) Ferr.) On snap beans in Ontario. Plant Health Prog. 10.1094/PHP-2005-1129-01-RS

CIMMYT. 1998. From agronomic data to farmers' recommendations. An Economics Training Manual, revised edition. Completely, D.F, Mexico.
Correa-Victoria, F. J., Pastor-Corrales, M. A., and Saettler, A. W. 1989. Angular leaf spot. Pages 59-75 in: Bean Production Problems in the Tropics. H. F. Schwartz and M. A. Pastor-Coralles, eds. Centro Internacional de Agricultura Tropical (CIAT), Cali, Colombia.

Egbe, O. M., and Idoko, A. J. 2012. Evaluation of Pigeon pea genotypes for intercropping with maize and sorghum in southern Guinea savanna: Economic benefits. Int. J. Agric. For. 2:108-114.

Farrar, J. F. 1992. Beyond photosynthesis: The translocation and respiration of diseased leaves. Pages 107-124 in: Pests and Pathogens: Plant Responses to Foliar Attack.BIOS Sci. Publ., Oxford, UK. P. G. Ayres, ed. UK.

Filho, A. B., Carneiro, S. M. T. P. G., Godoy, C. V., Amorim, L., Berger, R. D., and Hau, B. 1997. Angular leaf spot of Phaseolus beans: Relationships between disease, health y leaf area, and yield. Phytopathology 87:506-515.

Godoy, C. V., Amorim, L., Filho, A. B., Silva, H. P., Silva, W. J., and Berger, R. D. 2003. Temporal progress of southern rust in maize under different environmental conditions. Phytopathology 28:273-278.

Katungi, E., Karanja, D., Wozemba, D., Mutuoki, T., and Rubyogo, J. C. 2011. A cost-benefit analysis of farmer based seed production for common bean in Kenya. Afr. Crop Sci. J. 19:409-415.

Lemessa, F., Sori, W., and Wakjira, M. 2011. Association between angular leaf spot (Phaeoisariopsis griseola (Sacc.) Ferraris) and common bean (Phaseolus vulgaris L.). yield loss at Jimma, Southwestern Ethiopia. Plant Pathol. 10:57-65.

Madden, L. V., and Nutter, F. W. 1995. Modeling crop losses at field scale. Can. J. Plant Pathol. 17:124-137.

McGrath, M. T. 2013. Efficacy of fungicide for managing powdery mildew in pumpkin. Plant Dis. Manage. Rept. 8:V204.

Monda, E. O., Sanders, F. E., and Hicks, A. 2001. Infection and colonization of leaf by Phaeoisariopsis griseola. Plant Pathol. 50:103-110.

Patterson, D. T., Duke, O. S., and Hoagland, E. R. 1978. Effect of irradiance during growth on adaptive photosynthetic characteristics of velvet leaf and cotton. Plant Physiol. 61:402-405.

Payne, R. W., Murray, D. A., Harding, S. A., Baird, D. B., and Soutar, D. M. 2011. An Introduction to GenStat for Windows, 14th Ed. VSN Int., Hemel Hempstead, UK.

Sileshi, F., Mohammed, A., Selvaraj, T., and Negeri, M. 2014. Field management of Anthracnose (Colletotrichum lindermuthianum) in common bean through foliar spray fungicides and seed treatment bioagents. Sci. Technol. Art Res. 3:19-25.

Simko, I., and Piepho, H. 2011. The area under the disease progress stairs: Calculation, advantage and application. Phytopathology 102:381-389.

Sinha, S. K. 1977. Yield, yield components and plant idiotypesin food legume. Pages 102-103 in: Food Legume Crops. Improvement and Production, FAO Plant Production and Protection Serials, Rome, Italy.

Stenglein, S., Ploper, L. D., Vizgarra, O., and Balatti, P. 2003. Angular leaf spot: A disease caused by the fungus Phaeiosariopsis griseola (Sacc.) Ferraris on Phaseolus vulgaris L. Adv. Appl. Microbiol. 52:209-243.

Su, G., Suh, S. O., Schneider, R. W., and Russin, J. S. 2001. Host specialization in the charcoal rot fungus, Macrophominaphaseolina. Phytopathology 91: 120-126.

Van Schoonhoven, A., and Pastor-Corrales, M. A. 1987. Standard system for the evaluation of bean germplasm. CIAT, Cali, Colombia.

Waggoner, P. E., and Berger, R. D. 1987. Defoliation, disease, and growth Phytopathology 77:393-398.

Walters, D. R., Havis, N. D., and Sablon, C. 2014. Control of foliar pathogens using a combination of resistance elicitors. Front. Plant Sci. 5:241-255. 